\title{
Issues on Design of Piled Raft Foundation
}

\author{
Padmanaban $\mathrm{M} \mathrm{S}^{1}$, Sreerambabu $\mathrm{J}^{2}$ \\ ${ }^{1}$ (Civil Engineering, Central Polytechnic College/ DOTE,Chennai, India) \\ ${ }_{2}^{2}$ (Civil Engineering ,TPGIT/ Anna UniversityChennai , India)
}

\begin{abstract}
A piled raft foundation consists of a thick concrete slab reinforced with steel which covers the entire contact area of the structure, in which the raft is supported by a group of piles or a number of individual piles. Bending moment on raft, differential and average settlement, pile and raft geometries are the influencing parameters of the piled raft foundation system. In this paper, a detailed review has been carried out on the issues on the raft foundation design. Also, the existing design procedure was explained..
\end{abstract}

Keywords: Raft foundation, differential settlement, soil

\section{Introduction}

Generally, piled raft foundation is adopted in a situation where the raft foundation is not alone satisfying the design requirement. Moreover, piled raft foundation can be recommended for the soil with low bearing capacity and supposed to bear a heavy load. Usage of piles along with the raft foundation reduces the settlement. Design of raft foundation consists of three stages. Firstly, using appropriate analysis, number of piles for the design settlement is assessed. Secondly, carrying out a detailed analysis where piles must be provided. In order to obtain the exact location and number of piles to be placed, a detailed design shall be conducted (Poulos, 2001). Additionally, effect of settlement on superstructures is explained in detail. Figure 1 describes sectional view of the geographic profile as well as piled raft foundation. The introduction of the paper should explain the nature of the problem, previous work, purpose, and the contribution of the paper. The contents of each section may be provided to understand easily about the paper.

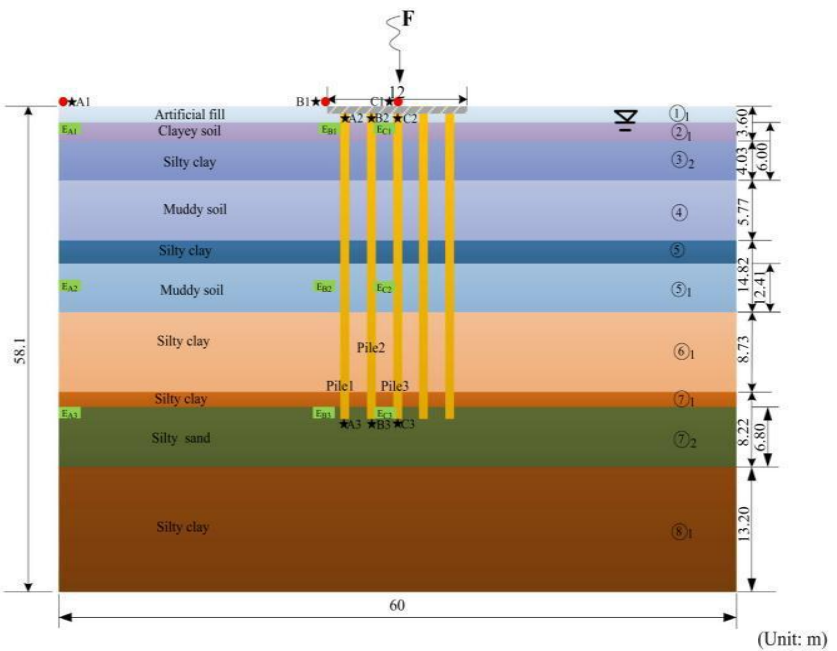

Figure 1 Piled raft foundation and details of geographic profile (Gu, Ye, Bao, \& Zhang, 2016).

In Figure 2, load-settlement curves of different conditions are shown, which includes raft only (curve 0 ), raft with pile designed for conventional safety factor (curve 1), piled raft designed for low safety factor (curve 2), piled raft with piles designed for full utilization of capacity (curve 3). For a constant load, maximum deflection is observed in raft foundation, whereas settlement seems to be minimum for the piled raft foundation with piles designed for full utilization of capacity. An investigation has been carried out by (Poulos, 1994) on soil profiles with relatively stiff clays and relatively dense sands, and it is concluded that raft foundation with piles can enhance the performance for both the conditions. On the other hand, unfavorable situations include soil profiles consists of soft clay and loose sands beneath the surface, soft compressible layers at shallow depths, strata likely to consolidate and swell. 


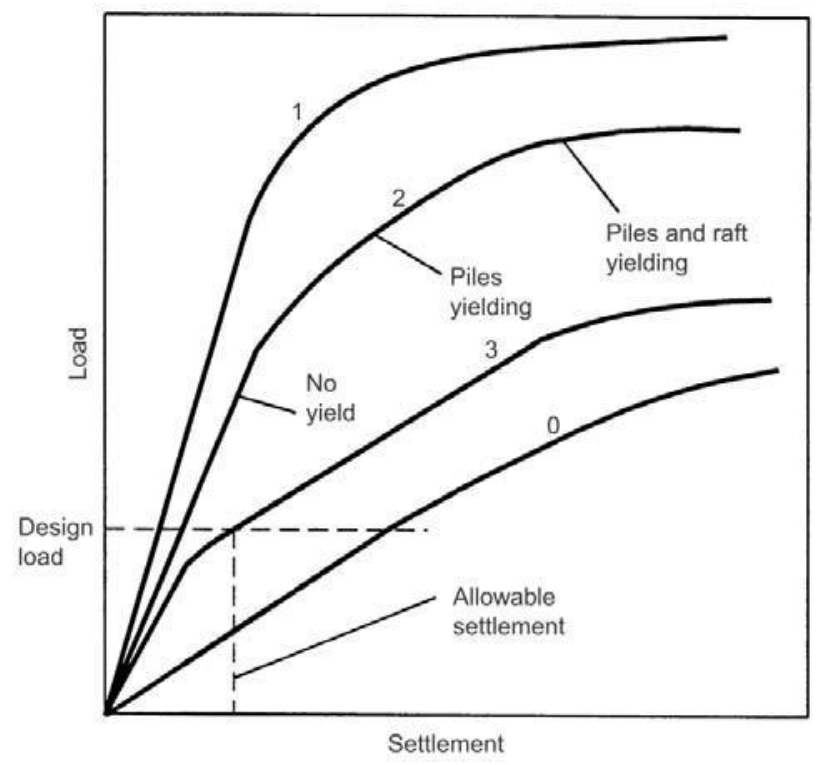

Figure 2 Load-settlement curves (Poulos, 2001)

\section{Effect of Settlement on Structure}

Rather than building collapse, the building will become unserviceable as a result of settlement. Due to tensile strain, the onset of wide crack can be seen in Figure 3. Cracks were appeared in the brick wall due to bending moments and shear force. Flexural cracks were developed when the bending moment exceeds the capacity, on the other hand, shear cracks emerged from the supports since the maximum shear force is at the supports. Also, it is to be noticed that cracking in concrete beams is in control, whereas the brick wall deforms drastically. Finally, it is emphasized that there is two modes of deformation can be observed, namely, shearing and bending. From the experimental results, it is observed that

deflection-to-span ratio $\left(\frac{\Delta}{L}\right)$ is more important than span-to-height ratio $\left(\frac{L}{H}\right)$. In addition, the relation between $\left(\frac{\Delta}{L}\right)$ and $\left(\frac{L}{H}\right)$

is linearly varying for distributed and concentrated type of loads (Burland \& Wroth, 1975).

Uniform settlement does not affect much, whereas the differential settlement can cause severe damage to the structure. The adverse effects of uneven settlement include tilting of chimney, leaking at the roofs, tilting of high-rise buildings, and the vertical overturning moment may cause catastrophic collapse too. Differential settlement can be identified by experiencing a large deformation at the top of the wall, on the other hand, negligible or meager deformation can be observed at the bottom. Further, the rate of crack growth will be very high.

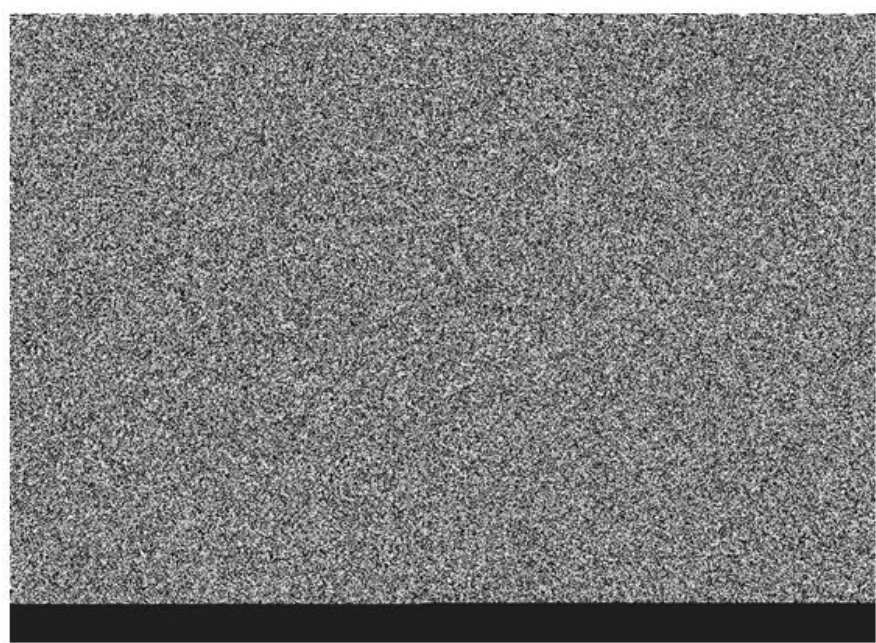

Figure 3 Cracking of brick wall due to bending moment (Burland \& Wroth, 1975) 


\section{Issues on Design of Foundation System}

Issues on the design of piled raft foundation include moment and shear force acting on rafts, differential settlement, maximum settlement and capacity of the piles and rafts. Note that contribution of raft in the piled raft foundation is neglected, though, it is contributing significantly. As a result, a number of piles installed is likely to be high when compared to the demand. The study carried out by (Horikoshi \& Randolph, 1998) concluded that total pile capacity should be $40-70 \%$ of the applied load.

The distribution of contract pressure under the applied uniform load below the rigid and flexible rafts are shown in Figure 4 (a) and (b). By introducing small pile groups as shown in Figure 4 (b), the differential settlement can be reduced significantly. As per studies by (Prakoso \& Fred H Kulhawy, 2001), settlement decreases when pile depth increases. Larger the area of the raft results in greater reduction of the settlement. As spacing between the piles increases, the settlement also increases. In other words, closely spaced piles reduce the displacements. Further, pile diameter and pile-to-raft area ratio increase the displacement decreases. Other influencing parameters were raft bending moments and pile butt load ratio.

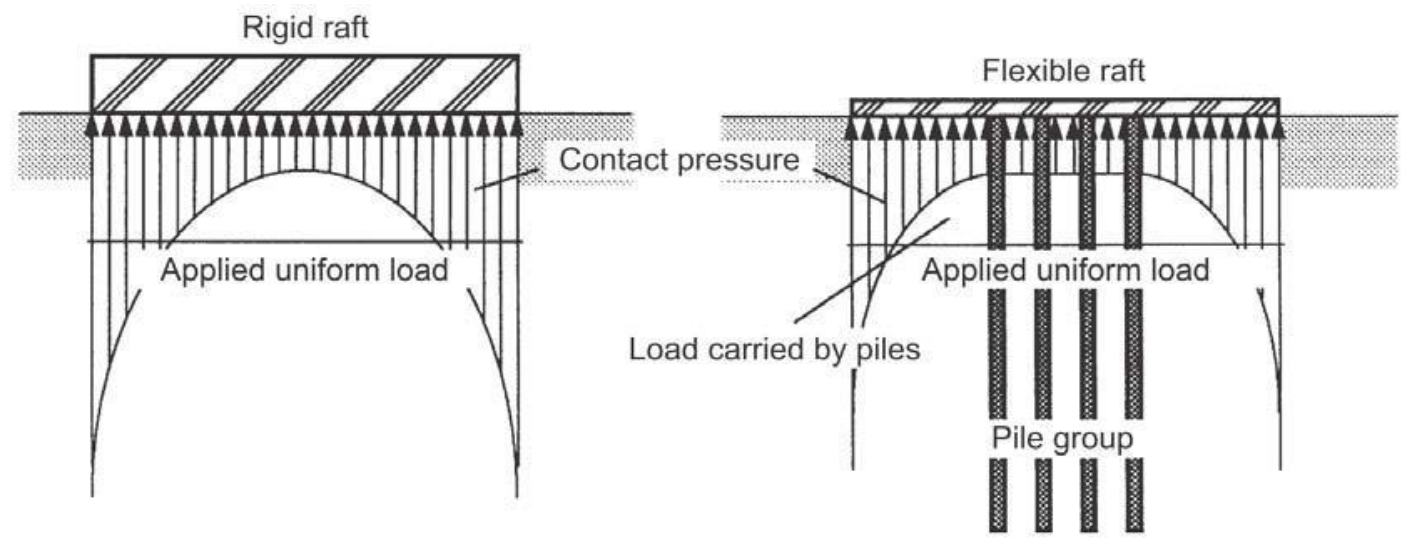

(a)

(b)

Figure 4 Distribution of contact pressure (a) rigid and (b) flexible rafts (Horikoshi \& Randolph, 1998)

\section{Behaviour of Piled-Raft Foundations Subjected To Moving Load}

The study carried on the piled-raft foundation subjected to high-speed train loads showed that improper treatment of soil might lead to drastic settlement (Gu, Ye, Bao, \& Zhang, 2016). When compared to static loading, the piled raft foundation is more vulnerable for dynamic loading. Soil penetrate easily when it is subjected to cyclic loading. After one-month trail run, calculated settlement is $8.9 \mathrm{~cm}$ whereas the measured is $5.0 \mathrm{~cm}$. Also, authors mentioned that data collected for that study was carried out at very low traffic volume, however, the results of settlement after one year may be more serious. In Figure 5 (a), variation of excitation force to operation time of train is shown. Consequently, Figure 5 (b) shows zoomed view of excitation force vs. time in seconds.

a

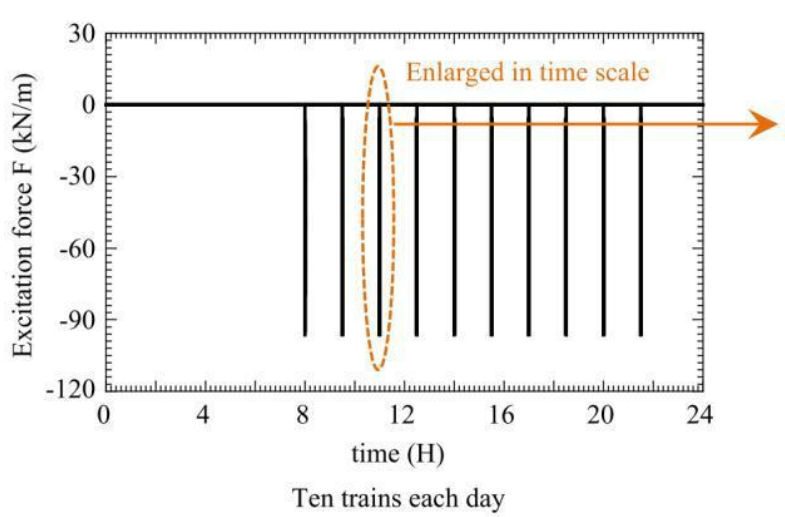

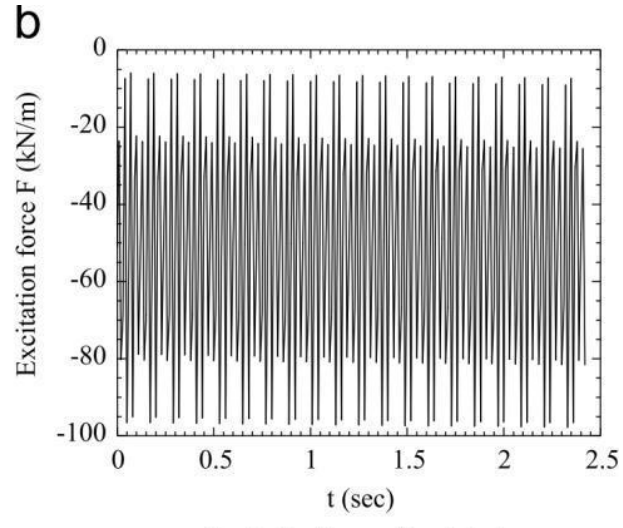

Excitationforce of each train

Figure 5 Loading due to high-speed train in one day (Gu, Ye, Bao, \& Zhang, 2016). 


\section{Piled Raft Foundation on Sand}

As previously mentioned, total and differential settlement, as well as induced moments on the rafts, are the crucial factors governing the design. Rather than placing piles uniformly, (Nguyen, Kim, \& Jo, 2014) suggested that concentrated pile arrangement beneath the raft could be the efficient and economic method. As shown in Figure 6, piles under the raft were configured and their efficiency were evaluated.

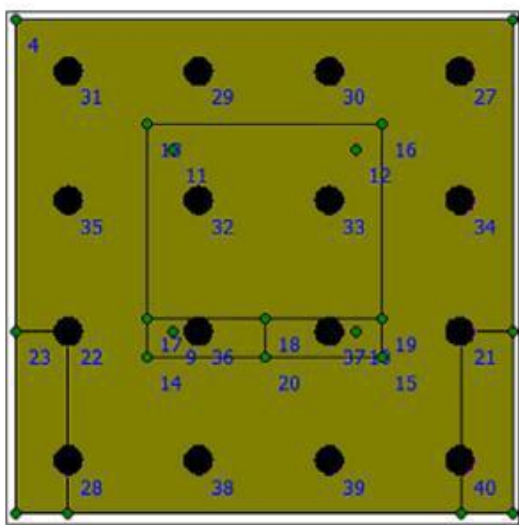

(a) Uniform

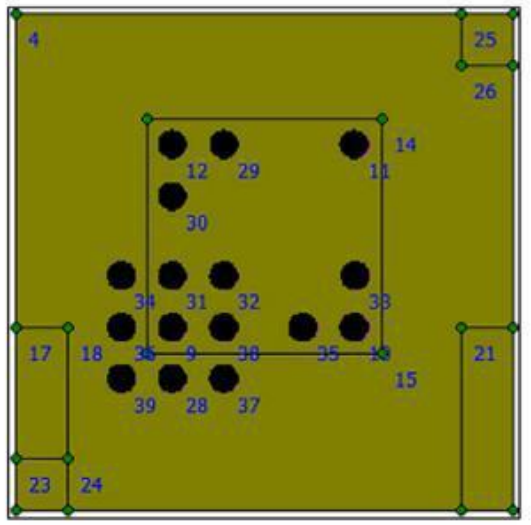

(c) Concentrate 2

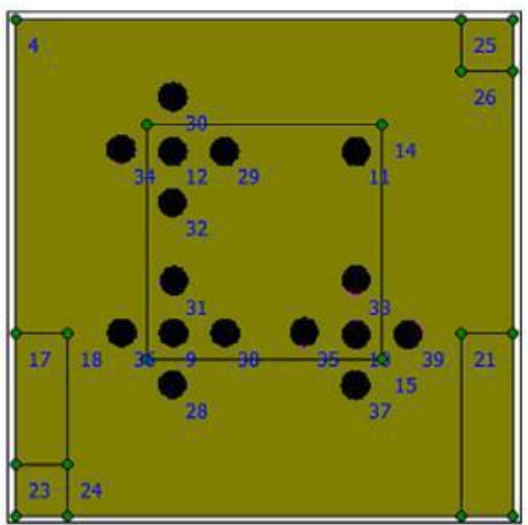

(b) Concentrate 1

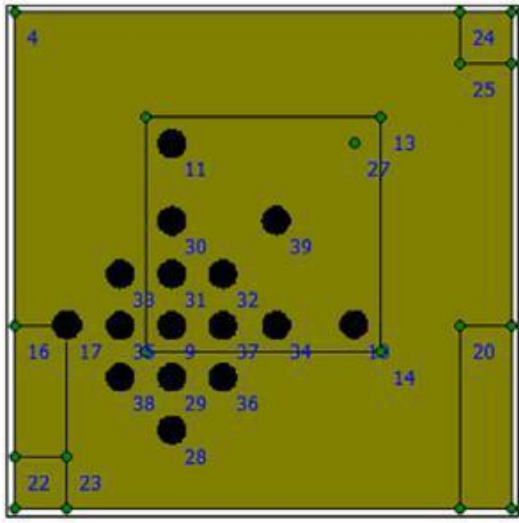

(d) Concentrate 3

Figure 6 Different types of pile arrangement (Nguyen et al., 2014)

\section{Piled Raft Foundation for High-Rise Buildings}

Piled raft foundation is befitting foundation system for the high-rise buildings. The foundation system should resist a combination of loads such as vertical, lateral and overturning moment. Incheon Tower, South Korea has been considered as case study by (Poulos, Small, \& Chow, 2011). In addition to settlement and load configuration issues, following issues can be expected in the design of foundation system for high-rise buildings. First, response of foundation system for the wind and earthquake is an important concern. Second, load distribution on piles. It is expected that piles and raft should share the total load equally. Last, movement of foundation system due to deep excavations in the adjacent site.

In the design implementation, followings things should be taken care: overall stability, serviceability and structural design requirements. For the stability check, forces and moment acting on the raft and piles should be for higher than the capacity. In this regard, necessary factor of safety can be used according to the code provisions. Next, for the serviceability analysis, deflection, rotation and crack width should be within the permissible limits.

\section{Existing Design Procedure for Pilled Raft Foundation}

Firstly, calculate the average and allowable differential settlement. If average settlement is critical, then the ratio of pile group width-to-raft width is equal to 1.0. On the other hand, if differential settlement is critical, then ratio of pile group width-to-raft width is in the range of 0.4 and 0.6. Subsequently, depth of the pile can be calculated based on allowable and differential settlement. 
Secondly, if both settlements are crucial, then ratio of pile group width-to-raft width can be considered in the range of 0.4 to 0.6 . Consequently, depth of the pile, D, can be calculated. Further, it has been checked that depth of the pile satisfies the demand, or else, the whole process should be repeated.

Thirdly, pile spacing, pile diameter, pile-to-raft area ratio, group pile capacity and individual pile capacity can be determined. Lastly, required raft thickness can be determined.

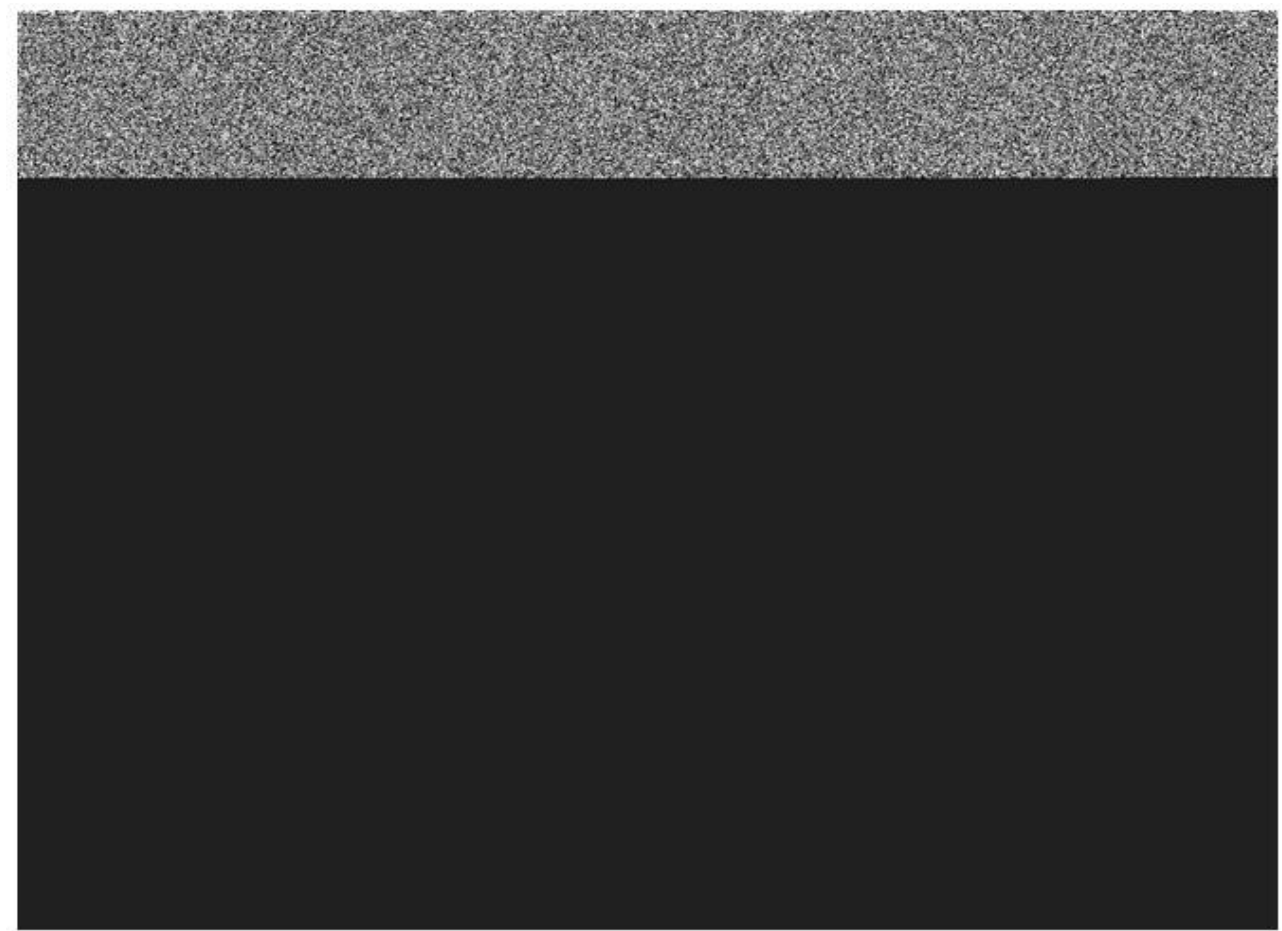

Figure 7 Flowchart for design of piled raft foundation (Prakoso \& Fred H Kulhawy, 2001)

\section{Conclusions}

Piled raft foundation can minimize the settlement even for relatively stiff and relatively dense sand. Spacing, diameter, depth, head, butt load and capacity of pile, geometry and capacity of the raft influences the settlement. As spacing between the piles decreases, settlement decreases. Further, relative settlement can be minimized when diameter of the pile and depth of the pile is more. A flow chart for the design of the piled raft foundation is explained.

\section{Acknowledgments}

Staff members and students of College of Engineering Guindy, Anna university Chennai for their support.

\section{References}

[1]. Burland, J. B., \& Wroth, C. P. (1975). Settlement of Buildings and Associated Damage. Proceedings of British Geotechnical Society Conference, (April).

[2]. Gu, L., Ye, G., Bao, X., \& Zhang, F. (2016). Mechanical behaviour of piled-raft foundations subjected to high-speed train loading. Soils and Foundations, 56(6), 1035-1054. https://doi.org/10.1016/j.sandf.2016.11.008

[3]. Horikoshi, K., \& Randolph, M. F. (1998). A contribution to optimum design of piled rafts. Géotechnique, 48(3), $301-317$. https://doi.org/10.1680/geot.1998.48.3.301

[4]. Nguyen, D. D. C., Kim, D. S., \& Jo, S. B. (2014). Parametric study for optimal design of large piled raft foundations on sand Computers and Geeotechnics, 55, 14-26. https://doi.org/10.1016/j.compgeo.2013.07.014

[5]. Poulos, H. G. (1994). An approximate numerical analysis of pile???raft interaction. International Journal for Numerical and Analytical Methods in Geomechanics, 18(2), 73-92. https://doi.org/10.1002/nag.1610180202

[6]. Poulos, H. G. (2001). Piled raft foundations: design and applications. Géotechnique, 51(2), 95-113. https://doi.org/10.1680/geot.51.2.95.40292

[7]. Poulos, H. G., Small, J. C., \& Chow, H. (2011). Piled Raft Foundations for Tall Buildings, 42 (June), 78-84.

[8]. Prakoso, W. A., \& Fred H Kulhawy. (2001). Contribution to Piled Raft Foundation Design. Journal of Geotechnical and Geoenvironmental Engineering, 127(January), 17-24. 